\title{
Effect of Anticonvulsant Drugs on the Rate of Folate Catabolism in Mice
}

\author{
Deirdre Kelly, Donald Weir, Berenice Reed, and John Scott, Departments of \\ Clinical Medicine and Biochemistry, Trinity College, Dublin 2, Ireland
}

A B S T RACT An increase in folate catabolism has been suggested as the cause of the folate deficiency observed in many clinical conditions, including chronic anticonvulsant therapy.

Previous studies have shown that the radioactive catabolites, excreted after an equilibration period of $3 \mathrm{~d}$, consisted exclusively of folates that had been cleaved to produce pteridines and $p$-aminobenzoylglutamate, most of which was excreted as acetamidobenzoylglutamate. We have developed an experimental animal model using mice to determine the rate of catabolism of $\left[{ }^{3} \mathrm{H}\right]$ pteroylglutamate (folic acid) by the quantitative estimation of $\left[{ }^{3} \mathrm{H}\right] p$-aminobenzoylglutamate and $\left[{ }^{3} \mathrm{H}\right]$ acetamidobenzoylglutamate in urine. Administration of diphenylhydantoin at three different doses $(0.5,20$, and $50 \mathrm{mg} / \mathrm{kg})$ significantly increased the rate of catabolism as measured by an increase in both the mean daily excretion and the cumulative excretion of these catabolites. Administration of intramuscular phenobarbitone on the other hand, did not affect the rate of catabolism, when compared with controls.

\section{INTRODUCTION}

Whereas folate deficiency is a well-recognized feature of chronic anticonvulsant therapy (1-3), the mechanism by which this happens is still controversial. Malabsorption of folate has been reported to occur (4-6) but has not been confirmed (7-11).

The fact that anticonvulsant drugs are known to induce hepatic enzymes $(12,13)$ has led to a further series of hypotheses. First, Richens and Waters (14) have suggested that folate deficiency may arise by induction of the enzymes involved in folate metabolism. Second, Maxwell et al. (15) proposed that it might be a result of an increase in the demand for the folate

This work was presented in part at the XVII Congress of the International Society of Haematology, Paris, France, 23-29 July 1978.

Received for publication $28 \mathrm{July} 1978$ and in revised form 27 April 1979. coenzymes required, either for anticonvulsant drug hydroxylation or for other hepatic enzymes induced by these drugs.

Increased catabolism of folate has also been suggested as the cause of the folate deficiency observed in many other clinical conditions, such as pregnancy, malignancy, hemolytic anaemia, and inflammatory disease (16).

Until recently the mechanism of folate catabolism was not known, and it was therefore not possible to confirm or refute the above-mentioned hypothesis. A number of studies in rats have shown that a tracer dose of high specific activity $\left[{ }^{3} \mathrm{H}\right]$ pteroylglutamate $(\mathrm{PteGlu})^{1}$ becomes fully equilibrated into the tissue folate polyglutamate pools after periods of 2 or $3 \mathrm{~d}$ (17). With such a tracer dose to label the endogenous pools we have recently elucidated the mechanism of folate catabolism in the rat (18), and have shown that it proceeds via cleavage of the C9-N10 bond of the molecule to yield pteridines, which are retained by the liver and released slowly (19), and $p$-aminobenzoylglutamate (pABGlu), most of which is first acetylated to produce acetamidobenzoylglutamate (ApABGlu) and then rapidly excreted in the urine (18). In the 1st $3 \mathrm{~d}$ after administration of labeled PteGlu, i.e., during the equilibration of the tracer dose, a complex mixture of folate derivatives is found in the urine $(18,20-25)$. After this time, however, only cleaved folate catabolites are found in the urine (20). Thus, because after equilibration each molecule of $\left[{ }^{3} \mathrm{H}\right] \mathrm{PteGlu}$ that is catabolized produces a molecule of either $\left[{ }^{3} \mathrm{H}\right]$ pABGlu or $\left[{ }^{3} \mathrm{H}\right] \mathrm{ApABGlu}$, it seems reasonable to suggest that the measurement of these two radioactive catabolites would be proportional to the rate of catabolism. These catabolites can only be quantitatively measured when hydrolyzed to $p$-aminobenzoic acid (pAB) (26). With this technique, we have developed an experimental animal model to measure

\footnotetext{
${ }^{1}$ Abbreviations used in this paper: ApABGlu, acetamidobenzoylglutamate; pAB, $p$-aminobenzoic acid; pABGlu, $p$ aminobenzoylglutamate; PteGlu, pteroylglutamate.
} 
the rate of folate catabolism by the quantitative estimation of these two catabolites in urine. This model was then used to investigate the effects of anticonvulsant therapy on the catabolic rate.

\section{METHODS}

Radiochemicals. $3^{\prime}, 5^{\prime}, 9(n)\left[{ }^{3} \mathrm{H}\right] \mathrm{Folic}$ acid (PteGlu) was supplied by The Radiochemical Centre, Amersham, U. K. Specific activity varied from 93 to $110 \mathrm{mCi} / \mathrm{mg}$ depending on the batch used. $\left[{ }^{3} \mathrm{H}\right] \mathrm{pAB}$ (100\% pure) was prepared by the same company by tritium gas exchange with halogenated $\mathrm{pAB}$ and had a specific activity $20 \mathrm{mCi} / \mathrm{mg}$. $\left[{ }^{3} \mathrm{H}\right]$ Hexadecane with a $2.17 \mu \mathrm{Ci} / \mathrm{mg}$ sp act and chromium [ $\left.{ }^{51} \mathrm{Cr}\right] \mathrm{EDTA}$ with a 700 $\mu \mathrm{Ci} / \mathrm{mg}$ sp act of chromium were also supplied by the Radiochemical Centre. $\left[2-{ }^{14} \mathrm{C}\right] \mathrm{PteGlu}$ potassium salt, $130 \mu \mathrm{Ci} / \mathrm{mg} \mathrm{sp}$ act, was also supplied by The Radiochemical Centre. $p$-Amino ${ }_{14}^{14}\left[\mathrm{CO}_{2} \mathrm{H}\right]$ benzoic acid, $0.3 \mathrm{mCi} / \mathrm{mg}$ sp act, was purchased from ICN Pharmaceuticals, Isotope and Nuclear Division, Irvine, Calif.

Anticonvulsant drugs. Diphenylhydantoin (phenytoin) suitable for injection was supplied by Parke, Davis \& Co., Pontypool, U. K., and phenobarbitone sodium was supplied by May and Baker Ltd., Dagenham, U. K.

Animals and treatment. Male and female Laca mice that weighed $\cong 20 \mathrm{~g}$ were given a single intraperitoneal injection of $4 \mu \mathrm{Ci}$ of $\left[{ }^{3} \mathrm{H}\right]$ PteGlu and $5 \mathrm{nCi}$ of $\left[{ }^{51} \mathrm{Cr}\right] \mathrm{EDTA}$. In any particular experiment either all males or all females were used. After administration of the radioactive dose, mice were randomly assigned to metabolic cages in groups of five, and their urines were collected daily for 10 or $14 \mathrm{~d}$. Each group of mice then received a daily injection for 10 or $14 \mathrm{~d}$. Control mice received $100 \mu \mathrm{l}$ of saline intramuscularly for the length of the experiment.

(a) Group A consisted of two cages of five mice in each group. Treated mice received $0.01 \mathrm{mg} / \mathrm{mouse}(\cong 0.5 \mathrm{mg} / \mathrm{kg})$ diphenylhydantoin intramuscularly for $14 \mathrm{~d}$. (b) Group B consisted of one cage of five mice in each group. Treated mice received $0.4 \mathrm{mg} /$ mouse $(\cong 20 \mathrm{mg} / \mathrm{kg}$ ) diphenylhydantoin per mouse intraperitoneally for $10 \mathrm{~d}$. This is considered a therapeutic anticonvulsant dosage for mice (27). (c) Group C consisted of two cages of five mice in each group. Diphenylhydantoin-treated mice received $1.0 \mathrm{mg} / \mathrm{mouse}(\cong 50 \mathrm{mg} / \mathrm{kg})$ intramuscularly for $10 \mathrm{~d}$; phenobarbitone-treated mice received $0.6 \mathrm{mg} / \mathrm{mouse}(\cong 30 \mathrm{mg} / \mathrm{kg}$ ) intramuscularly for $10 \mathrm{~d}$. All injections were administered in sterile saline except for phenobarbitone which was administered in distilled water. No other carriers were added. All groups of mice were kept in similar conditions and fed identical folate-replete diets ad libitum.

Estimation of $\left[{ }^{51} \mathrm{Cr}\right]$ EDTA. Urinary excretion of $\left[{ }^{51} \mathrm{Cr}\right]-$ EDTA was estimated on days 1 and 2 by direct counting of urine in a Nuclear-Chicago automatic gamma counter ( Nuclear-Chicago Corp., Des Plaines, Ill.). Because $90 \%$ of the administered $\left[{ }^{51} \mathrm{Cr}\right]$ EDTA is excreted within $24 \mathrm{~h}$ in humans (28), it was felt that measurement of this isotope would monitor the completeness of both injection and collection techniques. In a control series of experiments, urinary recovery of intraperitoneally administered $\left[{ }^{51} \mathrm{Cr}\right] \mathrm{EDTA}$ was $77-82 \%$; this range was used for reference.

Development of a method for estimation of $\left[{ }^{3} \mathrm{H}\right] \mathrm{pABGlu}$ and $\left[{ }^{3} \mathrm{H}\right] \mathrm{ApABGlu}$. A method for the hydrolysis of all folate derivatives to $\mathrm{pAB}$ and its subsequent estimation has been devised (26). After hydrolysis in $10 \mathrm{M}$ of $\mathrm{KOH}$ for $90 \mathrm{~min}$ at $120^{\circ} \mathrm{C}$ and $15 \mathrm{lb} / \mathrm{in}^{2}, 100 \%$ of the folate derivatives were converted to $\mathrm{PAB}$ when analyzed by chromatography on QAE A25 Sephadex (Pharmacia Fine Chemicals, Inc., Piscataway, N. J.) and the Bratton and Marshall technique (29). The pAB was then extracted with diethylether in which it was highly soluble at $\mathrm{pH}$ 3.75. Each sample was extracted three times with $5 \mathrm{ml}$ of diethylether, the ether evaporated to dryness, and then the sample was reconstituted with $1 \mathrm{ml}$ of distilled water and $10 \mathrm{ml}$ toluene Triton X-100 (Rohm and Haas Co. Philadelphia, Pa.). The efficiency of this procedure was found to be between 85 and $87 \%$ with $\left[{ }^{14} \mathrm{C}\right] \mathrm{pAB}$ in recovery experiments (26). When this technique was repeated with $\left[{ }^{3} \mathrm{H}\right] \mathrm{pAB}$, only $23-30 \%$ of the added radioactivity was retrieved. It was felt that this implied adsorption of tritium label to the glass vials during evaporation, with consequent decreased counting efficiency, rather than failure to extract added $\left[{ }^{3} \mathrm{H}\right] \mathrm{pAB}$. Preliminary attempts to prevent adsorption of tritium by using plastic vials, and by evaporating the diethylether over distilled water were unsuccessful. However, reproducible results were obtained when the diethylether was added directly to the scintillation fluid. In a control series of experiments, addition of $5 \mathrm{ml}$ of diethylether to $10 \mathrm{ml}$ of toluene:2,5-diphenyloxazole scintillation fluid caused radioactive quenching of $6-$ $18 \%$. When the diethylether was allowed to evaporate from the fluid before estimation, quenching was reduced to $0.5-$ $7.0 \%$. Using this procedure to extract known quantities of $\left[{ }^{3} \mathrm{H}\right]-$ $\mathrm{pAB}$ from urine, the mean efficiency was $76 \%$, quenching being assessed with $\left[{ }^{3} \mathrm{H}\right]$ hexadecane as the internal standard.

A further test of this method was performed. Known quantities of $\left[{ }^{3} \mathrm{H}\right]$ PteGlu were added to urine, hydrolyzed, and the subsequent $\left[{ }^{3} \mathrm{H}\right] \mathrm{pAB}$ was extracted as described. Quenching in control and extracted samples was estimated with $\left[{ }^{3} \mathrm{H}\right]$ hexadecane as an internal standard. A total of 36 extractions were performed in batches of six. For each batch examined, the mean percentage of radioactivity retrieved varied from 25 to $31 \%$ with an overall mean of $27.6 \pm 4.1$ (SEM). In the batch of $\left[{ }^{3} \mathrm{H}\right]$ PteGlu used, $35 \%$ of the tritium labeled the $3{ }^{\prime}, 5^{\prime}$-positions and was therefore available as $\left[{ }^{3} \mathrm{H}\right] \mathrm{pAB}(30)$. This implied that a mean of $79 \%$ of the available $\left[{ }^{3} \mathrm{H}\right] \mathrm{pAB}$ was extracted.

It was important to ensure that $\left[{ }^{3} \mathrm{H}\right]$ pteridines cleaved during alkaline hydrolysis were not also estimated by this method (Fig. 1). Samples of urine that contained known quantities of $\left[2-{ }^{14} \mathrm{C}\right]$ PteGlu labeled on the 2-position of the molecule (Fig. 1) were hydrolyzed and extracted as described. The radioactivity retrieved was at background level, representing $0.3 \%$ of the added $\left[2-{ }^{14} \mathrm{C}\right]$ PteGlu. Clearly, the pteridine moiety was not estimated by this method.

Experimental procedure. Quadruplicate samples of urine were hydrolyzed in $10 \mathrm{M} \mathrm{KOH}$ for $90 \mathrm{~min}$ at $120^{\circ} \mathrm{C}$ and $15 \mathrm{lb} / \mathrm{in}^{2}$. Samples were then adjusted to $\mathrm{pH} 3.75$ with concentrated $\mathrm{HCl}$, and the $\left[{ }^{3} \mathrm{H}\right] \mathrm{pAB}$ present was extracted as described. The radioactivity present was estimated, and quenching was assessed with $\left[{ }^{3} \mathrm{H}\right]$ hexadecane as an internal standard. To assess reproducibility of the procedure, two control samples which contained known quantities of $\left[{ }^{3} \mathrm{H}\right]$ PteGlu were assayed with each batch of experimental samples.

Estimation of tofal radioacticitiy. Total excreted radioactivity was determined by direct estimation of $100 \mu \mathrm{l}$ of urine

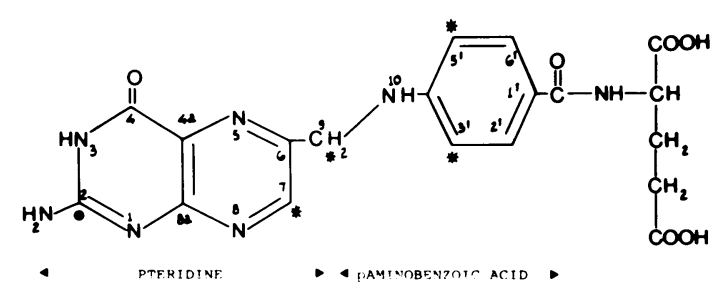

Figure 1 Structure of PteGlu showing the positions labeled with ${ }^{14} \mathrm{C}$ and ${ }^{* 3} \mathrm{H}$. 
in toluene:Triton X-100 scintillation fluid (31) with a Packard liquid scintillation counter (Packard Instrument Co., Downers Grove, Ill.).

Column chromatography. Analysis of the folate catabolites in mouse urine was performed on QAE.A25 anion exchange resin (Pharmacia Inc., Uppsala, Sweden) as previously described $(18,20)$.

Statistical methods. The significance of the difference between mean daily excretion and cumulative excretion of $\left[{ }^{3} \mathrm{H}\right]-$ pAB catabolites in control and treated groups was determined (32).

\section{RESULTS}

Animals. There was an initial weight loss of 1-2 $\mathrm{g} /$ mouse in all groups when they were placed in the metabolic cages. This stabilized once they became adjusted. There was no significant difference in dietary and fluid intake, or urinary output or weight loss detected in any of the groups.

Excretion of $\left[{ }^{51} \mathrm{Cr}\right] E D T A$. Excretion of $\left[{ }^{51} \mathrm{Cr}\right] \mathrm{EDTA}$ in a typical experiment was $72 \%$ over $24 \mathrm{~h}$ in the control group; $68 \%$ in diphenylhydantoin group $\mathrm{A} ; 78 \%$ in group B; $70 \%$ in group $C$; and $74 \%$ in the phenobarbitone group, which implies that injection and collection techniques were comparable in all groups.

Effect of urinary metabolites. To ensure that the urinary metabolites of diphenylhydantoin (5-[p-hydroxyphenyl]-5-phenylhydantoin) or metabolites of phenobarbitone ( $p$-hydroxy-phenobarbitone) did not interfere with the extraction procedure, known quantities of $\left[{ }^{3} \mathrm{H}\right] \mathrm{PteGlu}$ were added to urine from groups of control and anticonvulsant-treated mice. Samples were hydrolyzed, and the subsequent $\left[{ }^{3} \mathrm{H}\right] \mathrm{pAB}$ was extracted as described. No difference between the percentage of radioactivity retrieved in the three groups was detectable.

Comparison of total excreted radioactivity on a daily basis in control, diphenylhydantoin-, and phenobarbitone-treated mice. Total excreted radioactivity was highest in the 1st $3 \mathrm{~d}$ in all groups, stabilizing after this time to an almost constant, although slightly diminishing, level. In a typical experiment there was no significant difference between diphenylhydantointreated groups and controls or phenobarbitone-treated mice in the 1st $3 \mathrm{~d}$ (Table I). However, on each subsequent day there was a statistically significant difference between the diphenylhydantoin-treated mice and the controls and phenobarbitone-treated mice.

Further analysis of this data was performed to produce a comparison of the mean daily excretion after day 3. Mean daily excretion for each of the groups after day 3 was: group A: controls: $6.0 \pm 0.3 \times 10^{4} \mathrm{cpm}$ (SEM), diphenylhydantoin-treated: $7.3 \pm 0.4 \times 10^{4} \mathrm{cpm}$ $(\mathrm{SEM})(P<0.001)$; group B: controls: $5.1 \pm 0.1 \times 10^{4}$ cpm (SEM), diphenylhydantoin-treated $7.5 \pm 0.2 \times 10^{4}$ cpm (SEM) $(P<0.001)$; group C: controls: $10 \pm 0.2$ $\times 10^{4} \mathrm{cpm}(\mathrm{SEM})$, diphenylhydantoin-treated: $17 \pm 0.3$
TABLE I

Effect of Anticonvulsant Therapy in a Typical Experiment on Total Excreted Radioactivity after Administration of $4 \mu \mathrm{Ci}\left[{ }^{3} \mathrm{H}\right]$ PteGlu

\begin{tabular}{|c|c|c|c|}
\hline \multirow[b]{2}{*}{ Day } & \multicolumn{3}{|c|}{ Total radioactivity excreted ${ }^{*}$} \\
\hline & Control mice & $\begin{array}{c}\text { Treated with } \\
0.6 \mathrm{mg} \text { of } \\
\text { phenobarbitone }\end{array}$ & $\begin{array}{c}\text { Treated with } \\
1.0 \mathrm{mg} \text { of } \\
\text { diphenylhydantoin }\end{array}$ \\
\hline & \multicolumn{3}{|c|}{$c p m$} \\
\hline 1 & $30.1 \pm 0.3 \times 10^{5} \ddagger$ & $23 \pm 0.2 \times 10^{5} t$ & $38 \pm 0.1 \times 10^{5} \ddagger$ \\
\hline 2 & $3.5 \pm 0.2 \times 10^{5}$ & $3.8 \pm 0.1 \times 10^{5} t$ & $3.2 \pm 0.1 \times 10^{5}$ \\
\hline 3 & $2.2 \pm 0.4 \times 10^{5} \ddagger$ & $2.5 \pm 0.1 \times 10^{5} t$ & $3.2 \pm 0.2 \times 10^{5}$ \\
\hline 4 & $1.4 \pm 0.3 \times 10^{5}$ & $1.2 \pm 0.2 \times 10^{5} \S$ & $2.2 \pm 0.2 \times 10^{511}$ \\
\hline 5 & $1.3 \pm 0.1 \times 10^{5}$ & $1.1 \pm 0.1 \times 10^{5} \oint$ & $2.1 \pm 0.2 \times 10^{511}$ \\
\hline 6 & $1.1 \pm 0.15 \times 10^{5}$ & $1.1 \pm 0.2 \times 10^{5} \S$ & $2.7 \pm 0.1 \times 10^{511}$ \\
\hline 7 & $0.9 \pm 0.05 \times 10^{5}$ & $0.9 \pm 0.15 \times 10^{5} \S$ & $2.5 \pm 0.2 \times 10^{511}$ \\
\hline 8 & $0.85 \pm 0.05 \times 10^{5}$ & $0.8 \pm 0.1 \times 10^{5} \oint$ & $1.9 \pm 0.2 \times 10^{511}$ \\
\hline 9 & $0.92 \pm 0.1 \times 10^{5}$ & $0.5 \pm 0.1 \times 10^{5} \oint$ & $1.9 \pm 0.2 \times 10^{5 \|}$ \\
\hline 10 & $0.80 \pm 0.2 \times 10^{5}$ & $0.4 \pm 0.05 \times 10^{5} \S$ & $1.6 \pm 0.2 \times 10^{511}$ \\
\hline
\end{tabular}

Data pooled from two cages of five mice in each group.

* Mean \pm SEM.

$\ddagger P>1.0$ significance between the means in all three groups. $\S P>1.0$ significance between control and phenobarbitonetreated groups.

" $P<0.001$ significance of the difference between the individual daily means in the diphenylhydantoin-treated group and controls and phenobarbitone-treated animals.

$\times 10^{4} \mathrm{cpm}(\mathrm{SEM})(P<0.001) ;$ phenobarbitone-treated: $8.4 \pm 0.2 \times 10^{4} \mathrm{cpm}(\mathrm{SEM})(P>1.0)$.

The variation in excretion between the different groups is because the proportion of the tritium label on the pAB part of the molecule which differs between the batches of $\left[{ }^{3} \mathrm{H}\right] \mathrm{PteGlu}$ used. However, the same batch was used for both control and treated groups in each study.

Comparison of $\left[{ }^{3} \mathrm{H}\right] p A B$-excreted radioactivity on a daily basis in control, diphenylhydantoin-, and phenobarbitone-treated mice. Estimation of these catabolites in the 1st $3 \mathrm{~d}$ was similar in all treated groups when compared with controls and phenobarbitone-treated groups (Fig. 2). After the 4th d however, radioactive excretion settled to an almost constant level. There was a definite increase in excretion of these catabolites in all treated groups when compared with controls or phenobarbitonetreated animals (Fig. 2). Mean daily excretion in the various groups was: group A: controls: $1.4 \pm 0.2 \times 10^{4}$ cpm (SEM), diphenylhydantoin-treated: $1.9 \pm 0.2 \times 10^{4}$ cpm (SEM) $(P<0.001)$; group B: controls: $1.5 \pm 0.3$ $\times 10^{4} \mathrm{cpm}(\mathrm{SEM})$, diphenylhydantoin-treated $2.7 \pm 0.3$ $\times 10^{4} \mathrm{cpm}(\mathrm{SEM})(P<0.001)$; group C: controls: 2.05 $\pm 0.4 \times 10^{4} \mathrm{cpm}$ (SEM), diphenylhydantoin-treated: $3.98 \pm 0.6 \times 10^{4} \mathrm{cpm}(\mathrm{SEM})(P<0.001)$; phenobarbitone-treated: $2.04 \pm 0.3 \times 10^{4} \mathrm{cpm}(\mathrm{SEM})(P>1.0)$. 

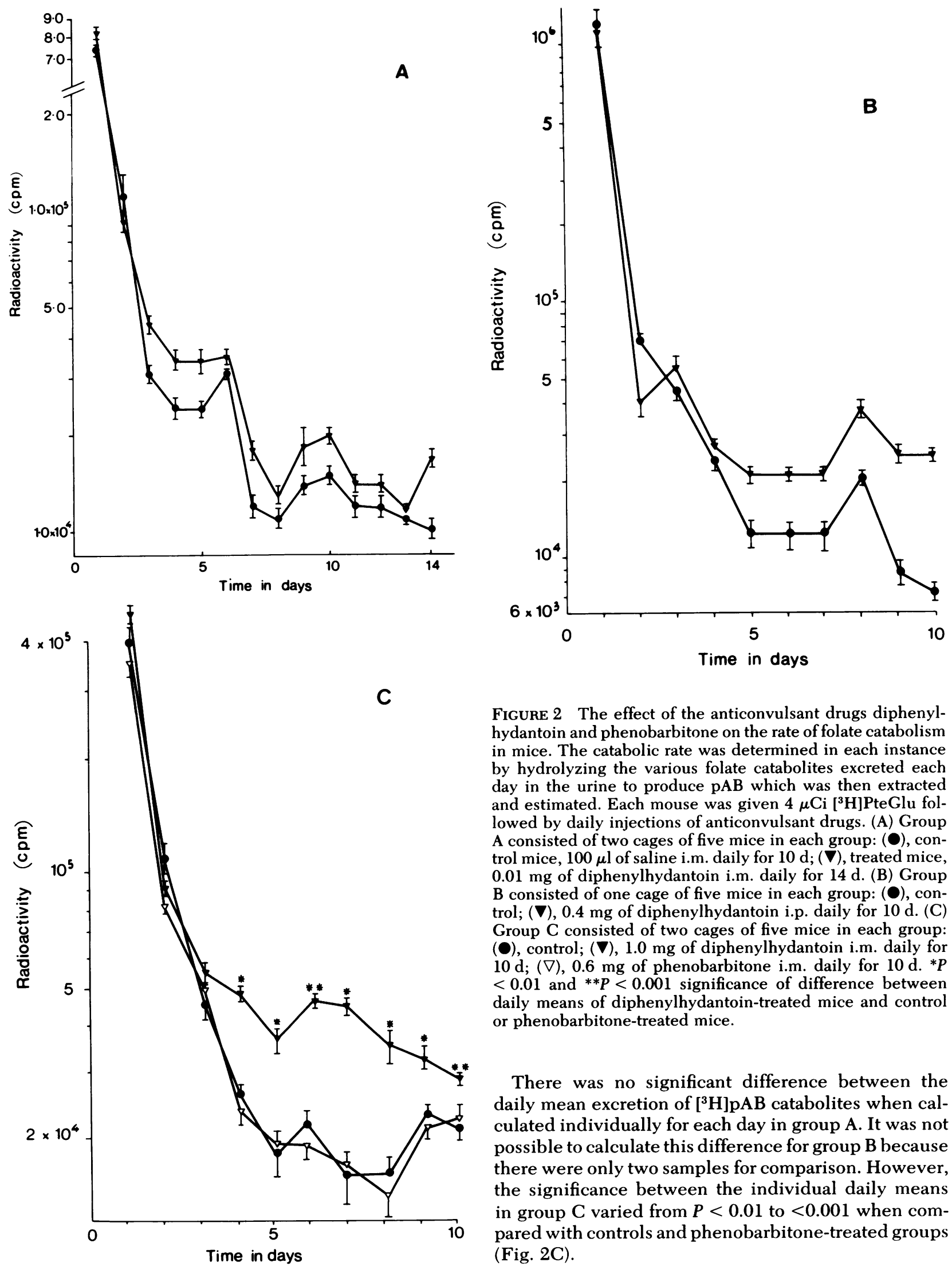

Figure 2 The effect of the anticonvulsant drugs diphenylhydantoin and phenobarbitone on the rate of folate catabolism in mice. The catabolic rate was determined in each instance by hydrolyzing the various folate catabolites excreted each day in the urine to produce $\mathrm{pAB}$ which was then extracted and estimated. Each mouse was given $4 \mu \mathrm{Ci}\left[{ }^{3} \mathrm{H}\right] \mathrm{PteGlu}$ followed by daily injections of anticonvulsant drugs. (A) Group A consisted of two cages of five mice in each group: (O), control mice, $100 \mu$ l of saline i.m. daily for $10 \mathrm{~d} ;(\nabla)$, treated mice, $0.01 \mathrm{mg}$ of diphenylhydantoin i.m. daily for $14 \mathrm{~d}$. (B) Group $B$ consisted of one cage of five mice in each group: (O), control; ( $\nabla), 0.4 \mathrm{mg}$ of diphenylhydantoin i.p. daily for $10 \mathrm{~d}$. (C) Group C consisted of two cages of five mice in each group: $(\Theta)$, control; ( $\nabla), 1.0 \mathrm{mg}$ of diphenylhydantoin i.m. daily for $10 \mathrm{~d} ;(\nabla), 0.6 \mathrm{mg}$ of phenobarbitone i.m. daily for $10 \mathrm{~d}$. ${ }^{*} P$ $<0.01$ and ${ }^{* *} P<0.001$ significance of difference between daily means of diphenylhydantoin-treated mice and control or phenobarbitone-treated mice.

There was no significant difference between the daily mean excretion of $\left[{ }^{3} \mathrm{H}\right] \mathrm{pAB}$ catabolites when calculated individually for each day in group $A$. It was not possible to calculate this difference for group $B$ because there were only two samples for comparison. However, the significance between the individual daily means in group $C$ varied from $P<0.01$ to $<0.001$ when compared with controls and phenobarbitone-treated groups (Fig. 2C). 
Comparison of cumulative excretion of both total and $\left[{ }^{3} \mathrm{H}\right] p A B$ radioactivity in controls, diphenylhydantoin-, and phenobarbitone-treated mice. Cumulative excretion of both total and $\left[{ }^{3} \mathrm{H}\right] \mathrm{pAB}$ radioactivity was calculated for the 1 st $3 \mathrm{~d}$ and then for the subsequent days of the experiment for each group.

There was no statistical difference between the cumulative excretion in either total or $\left[{ }^{3} \mathrm{H}\right] \mathrm{pAB}$ radioactivity in the 1st $3 \mathrm{~d}$ in any of the treated groups when compared with control or phenobarbitonetreated animals (Table II). However, there was a statistically significant increase in the cumulative excretion of both total and $\left[{ }^{3} \mathrm{H}\right] \mathrm{pAB}$ radioactivity noted from during day 4-14 in group $A$ and 4-10 in groups $B$ and C (Table II) in all diphenylhydantoin-treated groups when compared with controls and phenobarbitonetreated animals (Table II).

To relate these results to the total dose of $\left[{ }^{3} \mathrm{H}\right] \mathrm{PteGlu}$ administered, the mean percentage of excreted dose was calculated and is given in Table II.

Chromatographic analysis of mouse urines. The results clearly indicate that diphenylhydantoin causes an increase in total radioactive excretion after day 3 (Table I) and also that this is a result of $\left[{ }^{3} \mathrm{H}\right] \mathrm{pAB}-$ containing metabolites (Fig. 2). To preclude the possibility that these increases were not in fact a result of increased catabolism but to diphenylhydantoin-mediated release of intact folates, a series of chromatographic studies were undertaken. Urines from both control and diphenylhydantoin-treated animals were analyzed by column chromatography as previously described $(18,20)$. As previously reported in the rat, urines from the initial $3 \mathrm{~d}$ showed the presence of intact folates, while after that time only radioactive pteridines or $\left[{ }^{3} \mathrm{H}\right] \mathrm{ApABGlu}$ or $\left[{ }^{3} \mathrm{H}\right] \mathrm{pABGlu}$ could be detected in either controls or treated animals.

\section{DISCUSSION}

Folate catabolites are excreted in the urine in trace amounts which are undetectable by any form of chemical assay. Because the excreted folates are inactive, they cannot be determined by microbiological assay. However, by using PteGlu of sufficiently high specific activity, it is possible to follow the rate of catabolism without disturbing the folate balance within the animal $(17,18)$. During the course of catabolism the folate molecules are cleaved into pteridines and pABGlu. The synthesis of high specific activity $\left[{ }^{3} \mathrm{H}\right] \mathrm{PteGlu}$ is such that it distributes the radioactivity within the original molecule in such a way that both sets of catabolites are labeled after cleavage $(18,30)$ (Fig. 1). In addition, it has now become apparent that initial estimates showing that only a small proportion of ${ }^{3} \mathrm{H}$ was attached to the pteridine were inaccurate (30) and that as much as $25 \%$ of the label resides at $\mathrm{C} 7$. Previous studies in this laboratory have qualitatively analyzed the daily excreted folates after injection of $\left[{ }^{3} \mathrm{H}\right] \mathrm{PteGlu}$ in rats (20). The pteridine catabolites are retained by the liver and excreted slowly whereas most of the pABGlu is

TABLE II

Effect of Anticonvulsant Therapy on Cumulative Excretion of Radioactivity after Administration of $4 \mu \mathrm{Ci}\left[{ }^{3} \mathrm{H}\right]$ PteGlu*

\begin{tabular}{|c|c|c|c|c|}
\hline & \multicolumn{2}{|c|}{$0-3 \mathrm{~d}$} & \multicolumn{2}{|c|}{$4-14 d(A)$ and $4-10 d(B+C)$} \\
\hline & $\begin{array}{c}\text { Total } \\
\text { radioactivity }\end{array}$ & {$\left[{ }^{3} \mathrm{H}\right] \mathrm{pAB}$} & $\begin{array}{c}\text { Total } \\
\text { radioactivity }\end{array}$ & {$\left[{ }^{3} \mathrm{H}\right] \mathrm{pAB}$} \\
\hline & \multicolumn{4}{|c|}{ Radioactivity $\mathrm{cpm} \times 10^{5}$} \\
\hline \multicolumn{5}{|l|}{ Group A } \\
\hline Control & $39 \pm 0.1(59) \ddagger$ & $8.6 \pm 0.1(13)$ & $6.0 \pm 0.1(9)$ & $1.3 \pm 0.2(1.9)$ \\
\hline Diphenylhydantoin $(0.01 \mathrm{mg})$ & $37 \pm 0.1(57)$ & $9.8 \pm 0.1(15)$ & $7.4 \pm 0.1(11) \S$ & $2.1 \pm 0.1(2.7) \S$ \\
\hline \multicolumn{5}{|l|}{ Group B } \\
\hline Control & $39 \pm 0.1(46)$ & $13 \pm 0.6(20)$ & $3.6 \pm 0.1(6)$ & $0.99 \pm 0.5(1.5)$ \\
\hline Diphenylhydantoin $(0.4 \mathrm{mg})$ & $28 \pm 0.1(42)$ & $11 \pm 0.3(17)$ & $5.8 \pm 0.2(9) \S$ & $1.8 \pm 0.3(2.8) \S$ \\
\hline \multicolumn{5}{|l|}{ Group C } \\
\hline Control & $36 \pm 0.2(43)$ & $6.3 \pm 0.4(6.3)$ & $7.2 \pm 0.2(9)$ & $1.4 \pm 0.1(1.7)$ \\
\hline Diphenylhydantoin $(1.0 \mathrm{mg})$ & $44 \pm 0.2(53)$ & $7.1 \pm 0.2(7.1)$ & $12.0 \pm 0.2(18) \S$ & $2.7 \pm 0.2(3.3) \S$ \\
\hline Phenobarbitone $(0.6 \mathrm{mg})$ & $29 \pm 0.1(35)$ & $5.0 \pm 0.3(6.1)$ & $6.1 \pm 0.2(7)$ & $1.4 \pm 0.2(1.6)$ \\
\hline
\end{tabular}

Groups A and C represent two cages of five mice in each group. Group B represents one cage of five mice only in each group.

* Mean \pm SEM.

$\$$ The percentages of dose administered are shown in parentheses.

$\S P<0.001$ significance of the difference between diphenylhydantoin-treated mice and control or phenobarbitone-treated mice. 
acetylated to form ApABGlu which is then excreted rapidly (19). Thus, because of the greatly varying retention of the different radioactive folate catabolites it is not possible to simply measure total radioactive excretion as an index of catabolic rate. Qualitative analysis of rat urine has shown that whereas there is initial excretion of both intact and cleaved folates, after the 3rd d, only $\left[{ }^{3} \mathrm{H}\right]$ pteridines, $\left[{ }^{3} \mathrm{H}\right] \mathrm{pABGlu}$, and $\left[{ }^{3} \mathrm{H}\right]-$ ApABGlu are found (20). The analysis performed in this study has confirmed that the pattern of excretion in mouse urine is essentially similar.

It therefore seems reasonable to suggest that measurement of $\left[{ }^{3} \mathrm{H}\right] \mathrm{pABGlu}$ and $\left[{ }^{3} \mathrm{H}\right] \mathrm{ApABGlu}$ from the 4th $d$ onward could be used to estimate the catabolic rate.

By using controled conditions we have devised a chemical procedure whereby the various folate catabolites are treated so as to give one molecule of $\mathrm{pAB}$ for each molecule of catabolized folate present. The pAB so produced is then extracted into an organic solvent, concentrated, and estimated. Control experiments with samples of the originally injected $\left[{ }^{3} \mathrm{H}\right]-$ PteGlu are carried out simultaneously to ensure reproducibility. The completeness of the injection and collection procedures was monitored with $\left[{ }^{51} \mathrm{Cr}\right]$ EDTA.

Estimations of both total radioactivity and $\left[{ }^{3} \mathrm{H}\right] \mathrm{pAB}$ were highest in the 1 st $3 \mathrm{~d}$ in all experiments. Radioactivity diminished steadily after this time to an almost constant, although slightly reducing, level over the next $10 \mathrm{~d}$ (Table I; Fig. 2). In most experiments, counts were too low after the 10th $\mathrm{d}$ for accurate estimation of $\left[{ }^{3} \mathrm{H}\right] \mathrm{pAB}$, and the experiments were discontinued.

The rapid excretion of urinary radioactivity in the 1 st $3 \mathrm{~d}$ coincides with the complex pattern of intact and cleaved folates reported by many studies $(18,20-25)$. It also coincides with the many studies that have shown that a proportion of a tracer dose of high specific activity $\left[{ }^{3} \mathrm{H}\right]$ PteGlu becomes fully equilibrated into tissue polyglutamates over the same period (17). For these reasons it is likely that the radioactivity measured in the 1 st $3 \mathrm{~d}$ represents excretion of excess or partially metabolized $\left[{ }^{3} \mathrm{H}\right] \mathrm{PteGlu}$ during equilibration with the tissue pool. This is further supported by the finding that estimations of $\left[{ }^{3} \mathrm{H}\right] \mathrm{pAB}$ catabolites, total radioactivity, and the percentage of excreted dose are similar in all experiments for this time period.

From the 3rd d onward, however, when only cleaved products are found in the urine, the urinary radioactivity stabilized to an almost constant level. This finding is compatible with the theory that it is a result of regular excretion of small amounts of catabolized $\left[{ }^{3} \mathrm{H}\right]-$ PteGlu. The extraction method described above measures only $\left[{ }^{3} \mathrm{H}\right]$ pAB-containing catabolites; radioactive pteridines, which will be present in variable and substantial amounts (20), will not be estimated. Whereas estimations up to the 3rd d will include molecules of intact as well as cleaved folate, after this time, as only cleaved products are present (20), it will only measure either $\left[{ }^{3} \mathrm{H}\right] p A B G l u$ or $\left[{ }^{2} \mathrm{H}\right] \mathrm{ApABGlu}$. Because each of these catabolites represents a molecule of cleaved folate, their combined measurement gives a quantitative estimation of the urinary excretion of radioactive folate catabolites. We feel that estimation of $\left[{ }^{3} \mathrm{H}\right] \mathrm{pAB}$, derived from urinary $\left[{ }^{3} \mathrm{H}\right] \mathrm{pABGlu}$ and $\left[{ }^{3} \mathrm{H}\right]-$ ApABGlu from day 4 on represents measurement of catabolism.

These data are compatible with earlier studies which suggested that there is more than one pool of body folate (33-35): a "newly absorbed" pool which has a short biological half-life and a tissue pool which has a longer half-life.

The effect of diphenylhydantoin was investigated at three different doses: a very low dose, which was considerably less than the therapeutic dose ( $1 / 40)$; a therapeutic dose; and a higher than therapeutic dose (27). It is probably not possible to compare these dosages with human dose regimes by merely correcting for weight and volume because the species difference may be important. Nevertheless, the effect of diphenylhydantoin was observed at all three doses, even the exceptionally low dose. There was no effect on the rapid urinary excretion of radioactivity in the 1st $3 \mathrm{~d}$. From the 4th $d$ onward, there was a definite increase in both daily (Table I) and cumulative excretion of total radioactivity (Table II) and of $\left[{ }^{3} \mathrm{H}\right]$ pAB (Fig. 2; Table II), which was most obvious at the highest dosage of diphenylhydantoin.

It is interesting to note that this increased excretion of folate catabolites was only observed at a time when cleaved products were maximal in the urine. This would suggest that diphenylhydantoin increased the quantity of catabolites excreted from the second folate metabolic pool. It is unlikely that this alteration in excretion could be caused by changes in diet alone because both control and treated animals were maintained on identical diets under similar conditions. It is also improbable that it is simply a result of increased excretion of intact folate, because, in this case one would expect an effect in the 1 st $3 \mathrm{~d}$ as well. Furthermore, the qualitative analysis of the urine showed that there was no difference in the pattern of catabolites excreted in treated and control mice, both urines containing cleaved products from the 3 rd d onwards. A further alternative is that diphenylhydantoin might induce rapid cellular or renal clearance of the metabolites. However, it has been our experience in other studies involving the measurement of acetylation of pABGlu that this compound and its acetylated counterpart are excreted within a matter of hours. This is in accordance with a large body of literature showing similar clearance rates for similar compounds (36). Furthermore, if any alteration in clearance rate did occur on an 
hourly or daily basis then it seems likely that it would be corrected for when the accumulated results of several days were considered. It is clear from Table II that when the cumulative excretions of days 4-10 were considered for each group that a statistically significant increase in excretion of catabolites was seen in the diphenylhydantoin groups when compared with control or phenobarbitone groups.

To prove that this alteration in catabolic rate was not a transient one, efforts were made to prolong the length of the experiment. This was not possible in experiments involving groups $\mathrm{B}$ and $\mathrm{C}$ because there was insufficient radioactivity in the urine after the 10th $d$ for accurate estimation. However, in group $A$ it was possible to continue for $14 \mathrm{~d}$ and the effect of diphenylhydantoin was maintained for this length of time. It was not possible to calculate the effect this increased excretion of folate catabolites might have had on the total body folate stores except to comment that all doses of diphenylhydantoin caused an $80-100 \%$ increase in excretion when compared with control and phenobarbitone-treated animals. It seems likely, considering the suggested long half-life of the tissue folate pool (3335 ), that such increased turnover might lead to the increased incidence of folate deficiency observed in patients on long-term diphenylhydantoin treatment (1-3).

Administration of phenobarbitone had no significant effect on the rate of folate catabolism when compared with controls. This observation concurs with the clinical impression that folate deficiency is more common during therapy with diphenylhydantoin than with phenobarbitone $(1,37)$.

The mechanism for diphenylhydantoin-induced catabolism, however, is not clear. Because both the anticonvulsant drugs investigated induce hepatic enzymes equivalently $(12,13)$ this appears unlikely to be the mechanism as previously suggested $(14,15)$. It is, of course, possible that diphenylhydantoin induces a specific enzyme, either folate dependent or nonspecifically related, that phenobarbitone does not. Alternatively, it is possible that they have entirely different mechanisms of action as demonstrated in their effects on calcium and vitamin D metabolism (38). Perhaps a more attractive explanation lies in the known chemical instability of the folate coenzymes. It is easy to imagine a wide range of possibilities from alteration of the environment within cells to accumulation of more labile forms, which could readily lead to marked increases and their destruction.

These results conflict with those of Krumdieck et al. (35). While working with a single patient they found diphenylhydantoin increased excretion of newly absorbed PteGlu but did not increase catabolism. However, these workers used $\left[2-{ }^{14} \mathrm{C}\right] \mathrm{PteGlu}$ which upon catabolism produces a labeled pteridine only, which has been found to be further metabolized to produce several different pteridines which are retained by the liver for prolonged periods (19). This retention may obscure the clear increase in the catabolic rate effected by diphenylhydantoin (Fig. 2) which was observed when the rapidly excreted catabolites ApABGlu and pABGlu were measured.

\section{ACKNOWLEDGMENTS}

We would like to thank Mrs. Elizabeth Wilson for her technical assistance; Dr. Michael Stuart for his statistical advice; and the Biomedical Trust and the Laboratory Development Fund for their financial support.

\section{REFERENCES}

1. Hawkins, C. F., and M. J. Meynell. 1958. Macrocytosis and macrocytic anaemia caused by anticonvulsant drugs. Q. J. Med. 27: 45-63.

2. Klipstein, F. A. 1964. Subnormal serum folate and macrocytosis associated with anticonvulsant therapy. Blood. 23: 68-86.

3. Reynolds, E. H. 1975. Chronic anti-epileptic toxicitya review. Epilepsia. 16: 319-352.

4. Hoffbrand, A. V., and T. F. Necheles. 1969. Mechanism of folate deficiency in patients receiving phenytoin. Lancet. II: $528-530$.

5. Rosenberg, I. H., H. A. Godwin, R. R. Streiff, and W. B. Castle. 1968. Impairment of intestinal deconjugation of dietary folate: a possible explanation of megaloblastic anaemia associated with phenytoin therapy. Lancet. II: 530-532.

6. Gerson, C. D., G. W. Hepner, N. Brown, N. Cohen, V. Herbert, and H. D. Janowitz. 1972. Inhibition by diphenylhydantoin of folic acid absorption in man. Gastroenterology. 63: 246-251.

7. Baugh, C. M., and C. L. Krumdieck. 1969. Effect of phenytoin on folic acid conjugases in man. Lancet. II: 519-521.

8. Bernstein, L. H., S. Gutstein, S. Weiner, and G. Efron. 1970. The absorption and malabsorption of folic acid and its polyglutamates. Am. J. Med. 48: 570-579.

9. Houlihan, C. M., J. M. Scott, P. H. Boyle, and D. G. Weir. 1972. The effect of phenytoin on the absorption of synthetic folic acid polyglutamate. Gut. 13: 189-190.

10. Perry, J., and I. Chanarin. 1972. Observations on folate absorption with particular reference to folate polyglutamates and possible inhibitors to its absorption. Gut. 13: 544-550.

11. Fehling, C., M. Jagerstad, M. Lindstrand, and A. K. Westesson. 1973. The effect of anticonvulsant therapy upon the absorption of folates. Clin. Sci. Mol. Med. 44: 595-600.

12. Conney, A. H. 1967. Pharmacological implications of microsomal enzyme induction. Pharmacol. Rev. 19: 317366.

13. Latham, A. N., L. Millbank, A. Richens, and D. J. F. Rowe 1973. Liver enzyme induction by anticonvulsant drugs and its relationship to disturbed calcium and folic acid metabolism. J. Clin. Pharmacol. 13: 337-342.

14. Richens, A., and A. H. Waters. 1971. An acute effect of phenytoin on serum folate concentration. Br. J. Pharmacol. 41: 414-415P.

15. Maxwell, J. D., J. Hunter, D. A. Stewart, S. Ardeman, and R. Williams. 1972. Folate deficiency after anticonvulsant drugs: an effect of hepatic enzyme induction? Br. Med. J. I: 297-299. 
16. Hoffbrand, A. V. 1971. The megaloblastic anaemias. In Recent Advances in Haematology. A. Goldberg and N. C. Brian, editors. Churchill-Livingstone, London. 1-76.

17. Scott, J. M., and D. G. Weir. 1976. Folate composition, synthesis and function in natural materials. IV. Clinics in Haematology. A. V. Hoffbrand, editor. W. B. Saunders Co. Ltd., London. 5: 547-568.

18. Murphy, M., M. Keating, P. Boyle, D. G. Weir, and J. M. Scott. 1976. The elucidation of the mechanism of folate catabolism in the rat. Biochem. Biophys. Res. Commun. 71: 1017-1024.

19. Reed, B., D. G. Weir, and J. M. Scott. 1978. The occurrence of folate-derived pteridines in rat liver. Clin. Sci. Mol. Med. 54: 355-360.

20. Murphy, M., and J. M. Scott. 1979. The turnover, catabolism and excretion of folate administered at physiological concentrations in the rat. Biochim. Biophys. Acta. 583, 535-539.

21. Johns, D. G., S. Sperti, and A. S. V. Burgen. 1961. The metabolism of tritiated folic acid in man. J. Clin. Invest. 40: $1684-1695$.

22. McLean, A., and I. Chanarin. 1966. Urinary excretion of 5methyltetrahydrofolate in man. Blood. 3: 386-387.

23. Chanarin, I., and A. McLean. 1967. Origin of serum and urinary methyltetrahydrofolate in man. Clin. Sci. (Oxf.). 32: $57-67$.

24. Blair, J. A., and E. Dransfield. 1971. The urinary excretion of orally administered pteroyl-L-glutamic acid by the rat. Biochem. J. 123: 907-914.

25. Barford, P. A., J. A. Blair, F. J. Staff, and M. A. K. Malghani. 1977. The metabolism of folates in the rat. Studies with $\left[{ }^{3} \mathrm{H}\right]$ and $\left[{ }^{14} \mathrm{C}\right]$ labelled folic acid in the presence and absence of methotrexate. Biochem. Soc. Trans. 5: 1316-1318.

26. Reed, B. 1977. Aspects of folate and vitamin $B_{12}$ metabolism. Ph.D. Thesis, Trinity College, Dublin.
27. Barnes, C. D., and L. G. Eltherington. 1973. Drug dosage in laboratory animals: a handbook. University of California Press, London. 2nd edition.

28. Chantler, C., E. S. Garnett, V. Parsons, and N. Veall. 1969. Glomerular filtration rate measurement in man using the single injection method using $\left[{ }^{51} \mathrm{Cr}\right]$ EDTA. Clin. Sci. (Oxf.). 37: 169-180.

29. Bratton, A. C., and E. K. Marshall. 1939. A new coupling component for sulphanilimide determination. J. Biol. Chem. 128: 537-550.

30. Zakrzewski, S. F., E. A. Evans, and R. F. Phillips. 1970. On the specificity of labelling in tritiated folic acid. Anal. Biochem. 36: 197-206.

31. Turner, J. C. 1969. Tritium counting with Triton X-100 scintillant. Int. J. Appl. Radiat. Isot. 20: 499-505.

32. Snedecor, G. W., and W. G. Cochran. 1967. Statistical Methods. The Iowa State University Press. 6th edition. $285-288$.

33. Shane, B., J. E. Watson, and E. L. Stokstad. 1977. Uptake and metabolism of $\left[{ }^{3} \mathrm{H}\right]$ folate by normal and by vitamin $\mathrm{B}_{12}$ deficient rats. Biochim. Biophys. Acta. 497: 241-252.

34. Lane, F., P. Goff, R. McGuffin, F. R. Eichner, and R. S. Hillman. 1976. Folic acid metabolism in normal, folate deficient and alcoholic man. Br. J. Haematol. 34: 489-500.

35. Krumdieck, C. L., K. Fukushima, T. Fukushima, T. Shiota, and C. E. Butterworth, Jr. 1978. A long term study of the excretion of folate and pterins in a human subject after ingestion of $\left[{ }^{14} \mathrm{C}\right]$ folic acid, with observations on the effect of diphenylhydantoin administration. Am. J. Clin. Nutr. 31: 88-93.

36. Willams, T. 1959. Detoxification mechanisms. Chapman and Hall, London. 2nd edition.

37. Miller, D. R. 1968. Serum folate deficiency in children receiving anticonvulsant therapy. Pediatrics. 41: 630-635.

38. Neale, G. 1976. Enzyme inducing agents and their effect on vitamin $\mathrm{D}$ metabolism. In Frontiers of Gastrointestinal Research. S. Karger, Basel. 2: 32-70. 